\title{
ANTIBIOTIC SUSCEPTIBILITIES OF STREPTOCOCCI FROM THE MOUTH AND BLOOD OF PATIENTS TREATED WITH PENICILLIN OR LINCOMYCIN AND CLINDAMYCIN
}

\author{
I. Phillits, Christine Warren, J. M. Harrison, P. Sharples, \\ LYN C. BALL*, AND M. T. PARKeR* \\ Departments of Microbiology and Oral and Maxillofacial Surgery, St Thomas' Hospital, \\ London SEI 7EH, and ${ }^{*}$ Central Public Health Laboratory, Colindale, London NW9 5 HT
}

IT is well known that when patients receive antibiotics the oral streptococcal flora regularly becomes resistant to the agent used (Krumwiede, 1949; Garrod and Waterworth, 1962; Naiman and Barrow, 1963; Tozer, Boutflower and Gillespie, 1966; Stirland and Shotts, 1967; Sprunt, Redman and Leidy, 1968; Bentley, Frank and Hahn, 1971; Drucker and Jolly, 1971; Phillips and Warren, 1972; Sukchotiratama, Linton and Fletcher, 1975). It is not known whether this is due to selection of resistant mutants from a variety of sensitive streptococcal strains, or to the enrichment of certain intrinsically resistant species that may be present in the flora in very small numbers or may be acquired from elsewhere by patients who are receiving antibiotics. The present study was designed to answer this question with reference to penicillin and lincomycin, and to compare the efficacies of these antibiotics in curtailing bacteriaemia after dental extraction.

\section{PATIENTS AND METHODS}

Patients. All patients needing dental clearance (total extraction) before operations on the heart, or dental clearance or extraction of third molars for purely dental indications, and seen during a 6-month period in St Thomas' Hospital, were included in the study. Their pre-operative condition was assessed as good, fair or poor on the results of a combined evaluation of oral hygiene, periodontal condition, including the determination of Russell's Index (Russell, 1956), and any obvious oral infection. Details of any antibiotic treatment received during the previous 3 months were recorded.

Prophylactic chemotherapy. All patients having a dental clearance before an operation on the heart were given lincomycin $600 \mathrm{mg}$ intramuscularly $1 \mathrm{~h}$ before extraction of the teeth, and then a course of oral clindamycin $150 \mathrm{mg}$ four times daily for 5 days. The remaining patients were alternately given no antibiotic, the same regimen as the cardiac patients, or benzylpenicillin $600 \mathrm{mg}$ intramuscularly $1 \mathrm{~h}$ pre-operatively followed by phenoxymethylpenicillin $250 \mathrm{mg}$ four times daily for 5 days.

Samples for bacteriological examination. Samples of blood were collected for culture at the time of intubation during the induction of general anaesthesia, and $2 \mathrm{~min}$. after the completion of the dental operation. The $20-\mathrm{ml}$ sample was divided between a $50-\mathrm{ml}$ bottle of warmed Reinforced Clostridial Medium (Oxoid CM149) and a 50-ml bottle of warmed digest broth containing glucose $0.1 \%(\mathrm{w} / \mathrm{v})$ and $p$-aminobenzoic acid $0.01 \%(\mathrm{w} / \mathrm{v})$ (Southern Group Laboratory $0505 \mathrm{~B}$ ), the latter bottle containing an iron nail. A small volume of blood $(1-2 \mathrm{ml})$ was retained for antibiotic assay. The first bottle was incubated anaerobically with

Received 14 Jan. 1976; accepted 16 Feb. 1976.

MED. MICROBKLL- - VOL. 9 (1976) 
the cap loose in a GasPak jar (Baltimore Biological Laboratory) and the other in an air incubator, both at $37^{\circ} \mathrm{C}$. Anaerobic conditions were used because we were also interested in isolating anaerobes for another purpose.

Duplicate subcultures were made from each blood-culture bottle after incubation for $24 \mathrm{~h}$, and then weekly until a total of five subcultures had been made, on to blood-agar plates (Oxoid CM271); one plate was incubated at $37^{\circ} \mathrm{C}$ in air plus $\mathrm{CO}_{2}(10 \%)$, and the other was incubated anaerobically.

Extracted teeth were placed in sterile containers (all from one patient in a single container) and transported to the laboratory in a thermally insulated container at the end of the operating session. On the 5th-7th post-operative day, sutures were removed from the gum, placed in sterile containers and taken to the laboratory.

In a preliminary experiment on seven patients who had received benzylpenicillin $600 \mathrm{mg}$ intramuscularly, blood collected post-operatively was divided into two portions and inoculated into two bottles of blood-culture medium, one of which contained penicillinase (BBL Penase Concentrate).

In the laboratory, teeth were scraped, particularly in the region of the cervical margin, scrapings pooled for each patient, and samples plated on blood agar, MacConkey's Agar (Oxoid CM7), Mitis-Salivarius Agar (Difco B298), and blood agar containing either penicillin $1 \mu \mathrm{g}$ per ml, tetracycline $2 \mu \mathrm{g}$ per ml, vancomycin $2 \mu \mathrm{g}$ per ml, rifampicin $1 \mu \mathrm{g}$ per ml or clindamycin $1 \mu \mathrm{g}$ per ml, and incubated aerobically at $37^{\circ} \mathrm{C}$ for $48 \mathrm{~h}$. Sutures were rubbed on the surface of the same range of media, all from each patient on the same plate, and incubated in the same way.

Streptococci were initially selected from the primary culture plates on the basis of their colonial morphology and the appearance of gram-stained films. A representative of each colonial type was taken from each medium, and each isolate was tested for the fermentation of mannitol and sorbitol, the hydrolysis of aesculin and arginine, and the production of acetylmethylcarbinol. A selection was then made of organisms with different morphology and different results in these tests, from antibiotic-free and from antibiotic-containing media. Organisms with identical results in biochemical tests but different antibiotic susceptibilities were included. Most of these organisms were submitted to additional biochemical and serological tests, and classified as described by Parker and Ball (1976).

Minimum inhibitory concentrations (MICs) of penicillin, clindamycin, cephaloridine, erythromycin and tetracycline were determined for all isolates on solid media. Antibiotics were incorporated in suitable concentrations in Diagnostic Sensitivity Test Agar (DST, Oxoid CM261). The inoculum, applied with a multiple inoculator, contained approximately $10^{4}$ colony-forming units. MICs were determined after incubation of the plates for $24 \mathrm{~h}$ at $37^{\circ} \mathrm{C}$, as the lowest concentrations of antibiotic completely inhibiting growth.

Serum concentrations of antibiotics were determined by standard large-plate assay.

\section{RESULTS}

Table I gives information about the state of the teeth and gums before operation, the dental procedures performed, and the history of previous chemotherapy in the groups of patients given each regimen of prophylaxis. Because allocation to these groups was not random, more patients in the lincomycin group than in the other two groups had severe dental disease, and required dental clearance.

The preliminary experiment on the effect of penicillinase showed that organisms were often still viable in the blood in the presence of penicillin. Five of seven cultures to which penicillinase was added yielded either streptococci or a variety of anaerobes, whilst only one of the same but untreated samples yielded growth. 
TABLE I

(A) Dental condition and procedures, and $(B)$ details of previous chemotherapy of patients in relation to the allocated regimen of prophylactic chemotherapy

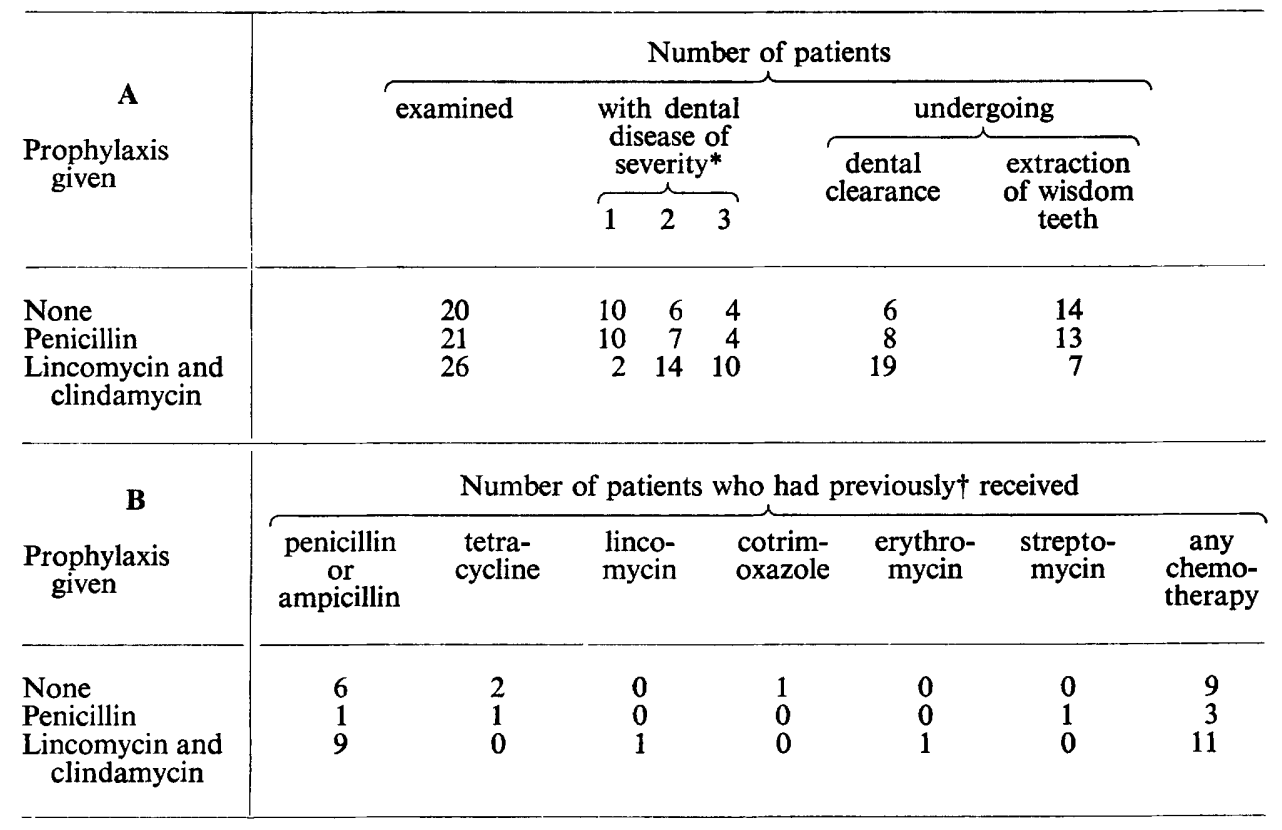

* See text for grading of severity.

$\dagger$ Within 3 months.

Streptococci isolated from teeth, blood and sutures

Of a total of 456 isolates, 449 were submitted to additional biochemical and serological tests. After full identification, 148 isolates were considered to be identical with others in biochemical reactions and antibiotic susceptibilities and were discarded. Table II lists the final collection of 301 streptococci isolated from teeth, blood and sutures. Of 21 isolates from blood, 17 came from the blood culture taken immediately after the dental operation. None of 21 patients receiving penicillin and only five of 26 receiving lincomycin yielded streptococci from blood cultures.

Among the predominantly " $\alpha$-haemolytic" taxa, we classified as Streptococcus sanguis 64 isolates that gave positive results in at least two of the three tests for aesculin hydrolysis, arginine hydrolysis, and the formation of dextran from sucrose, and as $S$. mitior 60 isolates that gave negative reactions in all three of these tests, but we classified separately as " $S$. mitior, dextran positive", 17 isolates that gave negative results in the aesculin- and arginine-hydrolysis tests but formed dextran (Colman and Williams, 1972). This left an unclassified " viridans" group of 33 dextran-negative isolates that gave a positive reaction in the arginine or the aesculin test but not in both. In addition to these we recognised 36 isolates each of $S$. mutans and S. milleri, 18 of S. salivarius, and 


\section{TABLE II}

Distribution of streptococcal species or groups among isolates from teeth, blood, or sutures of 88 patients

\begin{tabular}{|c|c|c|c|c|c|c|c|}
\hline \multirow{2}{*}{$\begin{array}{l}\text { Species or group of } \\
\text { Streptococcus }\end{array}$} & \multicolumn{7}{|c|}{$\begin{array}{c}\text { Numbers (and percentages) of the stated categories of streptococci } \\
\text { isolated from }\end{array}$} \\
\hline & $\begin{array}{l}\text { teeth* of } \\
49 \text { patients }\end{array}$ & $\begin{array}{l}\text { blo } \\
67 \mathrm{p}\end{array}$ & $\begin{array}{l}\text { d广 of } \\
\text { atients }\end{array}$ & sutu $37 \mathrm{p}$ & $\begin{array}{l}\text { est of } \\
\text { atients }\end{array}$ & & sites \\
\hline $\begin{array}{l}\text { sanguis } \\
\text { mitior } \\
\text { mitior, dextran positive } \\
\text { "viridans" } \\
\text { mutans } \\
\text { milleri } \\
\text { salivarius } \\
\text { faecalis } \\
\text { Other enterococci } \\
\text { Group C } \\
\text { Other mannitol fermenting } \\
\text { Other laevan positive } \\
\text { Unidentified }\end{array}$ & 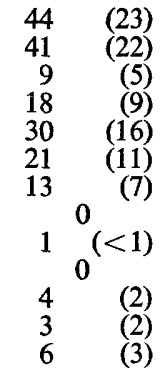 & $\begin{array}{l}1 \\
6 \\
4 \\
1 \\
5\end{array}$ & $\begin{array}{lr} & (5) \\
& (29) \\
0 & \\
& (19) \\
& (5) \\
& (24) \\
0 & \\
0 & \\
& \\
0 & (5) \\
0 & (5) \\
& \\
& (5) \\
& (5)\end{array}$ & $\begin{array}{r}19 \\
13 \\
8 \\
11 \\
5 \\
10 \\
5 \\
11 \\
1 \\
1 \\
1\end{array}$ & 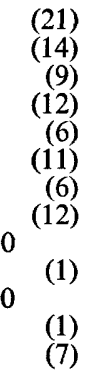 & $\begin{array}{r}64 \\
60 \\
17 \\
33 \\
36 \\
36 \\
18 \\
11 \\
2 \\
1 \\
5 \\
5 \\
13\end{array}$ & $\begin{array}{r}(21) \\
(20) \\
(6) \\
(11) \\
(12) \\
(12) \\
(6) \\
(4) \\
(<1) \\
(<1) \\
(2) \\
(2) \\
(4)\end{array}$ \\
\hline Any streptococcus & $(100)$ & 21 & $(100)$ & 90 & $(100)$ & 301 & $(100)$ \\
\hline
\end{tabular}

* After extraction.

$\dagger$ Before dental extraction, 4 isolates; immediately afterwards, 17 isolates.

$\ddagger$ Five to 7 days after the extraction of teeth.

TABLE III

Streptococci isolated from teeth, blood and sutures* of patients receiving no prophylaxis, penicillin, or lincomycin and clindamycin

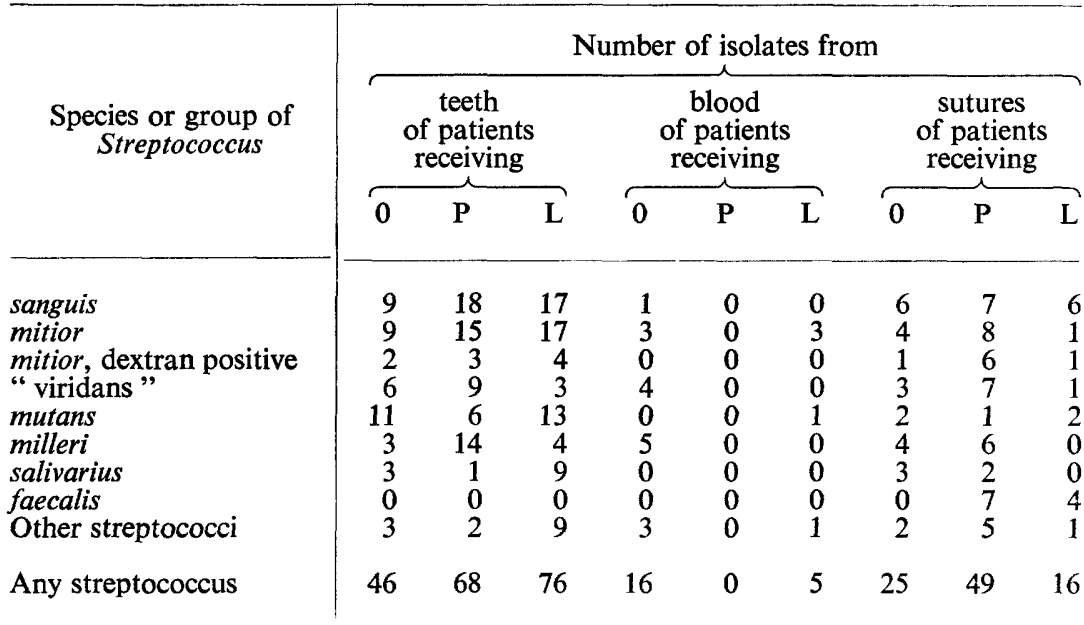

$\mathbf{0}=$ No antibiotic; $\mathbf{P}=$ penicillin $; \mathbf{L}=$ lincomycin and clindamycin.

* See footnotes to table II. 
11 of $S$. faecalis, two of other enterococci, and one $\beta$-haemolytic group-C streptococcus. Unclassified isolates included five mannitol-fermenting, bilesensitive non-dextran-forming streptococci, five laevan-producing streptococci that differed from $S$. salivarius in their arginine or sugar reactions or both, and 13 other single isolates that could not be allocated to any group.

The major difference in the range of streptococci isolated from the three sites was the absence of faecal streptococci from the teeth and the blood and their presence in the sutures, in all cases in patients who had received antibiotics (table III). Other differences, such as the non-isolation of $S$. salivarius and dextran-positive $S$. mitior strains from the blood cultures and the rarity of $S$. mutans in the blood, are not statistically significant, but are of interest.

\section{Sensitivities of the isolates to penicillin and clindamycin}

Table IV shows the distribution of MICs of penicillin for each species isolated. Most of the isolates of each of the organisms, with the exception of $S$. faecalis, were inhibited by penicillin $0.12 \mu \mathrm{g}$ per $\mathrm{ml}$ or less, but each species or group included some isolates that were more resistant; most of the $S$. faecalis, and an occasional isolate of each of the other common species, were even more resistant, with an MIC in excess of $1 \mu \mathrm{g}$ per $\mathrm{ml}$. The percentage of resistant strains was greatest among isolates from sutures-12\% had an MIC of $0.25-1.0 \mu \mathrm{g}$ per $\mathrm{ml} ; 21 \%$ had an MIC of $>1.0 \mu \mathrm{g}$ per ml-and least among those from teeth-4\% had an MIC of $0.25-1.0 \mu \mathrm{g}$ per ml; $3 \%$ had an MIC of $>1.0 \mu \mathrm{g}$ per $\mathrm{ml}$. This difference was only partly accounted for by the fact that the isolates from the sutures included all 11 of the $S$. faecalis strains.

TABLE IV

Penicillin sensitivities of isolates of various species or groups of streptococci

\begin{tabular}{|c|c|c|c|c|c|}
\hline \multirow{2}{*}{$\begin{array}{l}\text { Species or group of } \\
\text { Streptococcus }\end{array}$} & \multirow{2}{*}{$\begin{array}{l}\text { Total number } \\
\text { of isolates }\end{array}$} & \multicolumn{4}{|c|}{$\begin{array}{l}\text { Percentage of isolates with a penicillin } \\
\text { MIC }(\mu \mathrm{g} \text { per } \mathrm{ml}) \text { of }\end{array}$} \\
\hline & & $<0.01$ & $0.01-0.12$ & $0.25-1.0$ & $>1 \cdot 0$ \\
\hline $\begin{array}{l}\text { sanguis } \\
\text { mitior } \\
\text { mitior, dextran positive } \\
\text { "viridans" } \\
\text { mutans } \\
\text { milleri } \\
\text { salivarius } \\
\text { faecalis } \\
\text { Other streptococci }\end{array}$ & $\begin{array}{l}64 \\
60 \\
17 \\
33 \\
36 \\
36 \\
18 \\
11 \\
26\end{array}$ & $\begin{array}{r}30 \\
12 \\
6 \\
6 \\
26 \\
8 \\
6 \\
0 \\
19\end{array}$ & $\begin{array}{r}66 \\
83 \\
65 \\
70 \\
60 \\
83 \\
72 \\
0 \\
65\end{array}$ & $\begin{array}{r}3 \\
2 \\
24 \\
3 \\
9 \\
6 \\
11 \\
18 \\
8\end{array}$ & $\begin{array}{r}1 \\
3 \\
5 \\
21 \\
5 \\
3 \\
11 \\
82 \\
8\end{array}$ \\
\hline $\begin{array}{l}\text { All streptococci from } \\
\text { teeth } \\
\text { blood } \\
\text { sutures } \\
\text { all sites }\end{array}$ & $\begin{array}{r}190 \\
21 \\
90 \\
301\end{array}$ & $\begin{array}{l}18 \\
10 \\
13 \\
16\end{array}$ & $\begin{array}{l}75 \\
75 \\
54 \\
68\end{array}$ & $\begin{array}{r}4 \\
5 \\
12 \\
7\end{array}$ & $\begin{array}{r}3 \\
10 \\
21 \\
9\end{array}$ \\
\hline
\end{tabular}


TABLE V

Penicillin sensitivities of streptococci from patients on the different antibiotic regimens

\begin{tabular}{|c|c|c|c|c|c|c|c|c|c|}
\hline \multirow{3}{*}{$\begin{array}{c}\text { Species or } \\
\text { group of } \\
\text { Streptococcus }\end{array}$} & \multicolumn{9}{|c|}{ Number of isolates, from patients who had received } \\
\hline & \multicolumn{3}{|c|}{$\begin{array}{l}\text { no antibiotic, } \\
\text { with a penicillin } \\
\text { MIC ( } \mu \mathrm{g} \text { per ml) of }\end{array}$} & \multicolumn{3}{|c|}{$\begin{array}{l}\text { penicillin, with a } \\
\text { penicillin MIC } \\
(\mu \mathrm{g} \text { per ml) of }\end{array}$} & \multicolumn{3}{|c|}{$\begin{array}{l}\text { lincomycin and } \\
\text { clindamycin, with a } \\
\text { penicillin MIC } \\
(\mu \mathrm{g} \text { per } \mathrm{ml}) \text { of }\end{array}$} \\
\hline & $\leqslant 0 \cdot 12$ & $0 \cdot 25-1 \cdot 0$ & $>1.0$ & $\leqslant 0 \cdot 12$ & $0 \cdot 25-1 \cdot 0$ & $>1 \cdot 0$ & $\leqslant 0 \cdot 12$ & $0 \cdot 25-1 \cdot 0$ & $>1 \cdot 0$ \\
\hline $\begin{array}{l}\text { sanguis } \\
\text { mitior } \\
\text { mitior, dextran } \\
\text { positive }\end{array}$ & $\begin{array}{r}16 \\
15 \\
2\end{array}$ & $\begin{array}{l}0 \\
1 \\
0\end{array}$ & $\begin{array}{l}0 \\
0 \\
1\end{array}$ & $\begin{array}{r}23 \\
21 \\
6\end{array}$ & $\begin{array}{l}2 \\
1 \\
3\end{array}$ & $\begin{array}{l}0 \\
1 \\
0\end{array}$ & $\begin{array}{r}22 \\
20 \\
4\end{array}$ & $\begin{array}{l}0 \\
0 \\
1\end{array}$ & $\begin{array}{l}1 \\
1 \\
0\end{array}$ \\
\hline $\begin{array}{l}\text { " viridans" } \\
\text { mutans } \\
\text { milleri } \\
\text { salivarius } \\
\text { faecalis } \\
\text { Other streptococci }\end{array}$ & $\begin{array}{r}10 \\
12 \\
12 \\
5 \\
0 \\
7\end{array}$ & $\begin{array}{l}0 \\
1 \\
0 \\
1 \\
0 \\
1\end{array}$ & $\begin{array}{l}3 \\
0 \\
0 \\
0 \\
0 \\
0\end{array}$ & $\begin{array}{r}12 \\
7 \\
17 \\
1 \\
0 \\
6\end{array}$ & $\begin{array}{l}1 \\
0 \\
2 \\
0 \\
0 \\
1\end{array}$ & $\begin{array}{l}3 \\
0 \\
1 \\
2 \\
7 \\
0\end{array}$ & $\begin{array}{r}3 \\
12 \\
4 \\
8 \\
0 \\
9\end{array}$ & $\begin{array}{l}0 \\
2 \\
0 \\
1 \\
2 \\
0\end{array}$ & $\begin{array}{l}1 \\
2 \\
0 \\
0 \\
2 \\
2\end{array}$ \\
\hline Any streptococcus & 79 & 4 & 4 & 93 & 10 & 14 & 82 & 6 & 9 \\
\hline
\end{tabular}

TABLE VI

Clindamycin sensitivities of streptococci ${ }^{*}$ from patients receiving the different antibiotic regimens

\begin{tabular}{|c|c|c|c|c|c|c|}
\hline \multirow{3}{*}{$\begin{array}{l}\text { Species or group of } \\
\text { Streptococcus }\end{array}$} & \multicolumn{6}{|c|}{ Number of isolates, from patients who had received } \\
\hline & \multicolumn{3}{|c|}{$\begin{array}{l}\text { no antibiotic or penicillin, } \\
\text { with a clindamycin MIC } \\
\text { ( } \mu \mathrm{g} \text { per ml) of }\end{array}$} & \multicolumn{3}{|c|}{$\begin{array}{l}\text { lincomycin and clindamycin } \\
\text { with a clindamycin MIC } \\
\text { ( } \mu \mathrm{g} \text { per ml) of }\end{array}$} \\
\hline & $\leqslant 0 \cdot 12$ & $0 \cdot 25-4 \cdot 0$ & $>4 \cdot 0$ & $\leqslant 0 \cdot 12$ & $0 \cdot 25-4 \cdot 0$ & $>4.0$ \\
\hline $\begin{array}{l}\text { sanguis } \\
\text { mitior } \\
\text { mitior, dextran positive } \\
\text { "viridans" } \\
\text { mutans } \\
\text { milleri } \\
\text { salivarius } \\
\text { faecalis } \\
\text { Other streptococci }\end{array}$ & $\begin{array}{r}41 \\
39 \\
3 \\
29 \\
20 \\
32 \\
9 \\
0 \\
13\end{array}$ & $\begin{array}{l}0 \\
0 \\
0 \\
0 \\
0 \\
0 \\
0 \\
0 \\
1\end{array}$ & $\begin{array}{l}0 \\
0 \\
0 \\
0 \\
0 \\
0 \\
0 \\
7 \\
0\end{array}$ & $\begin{array}{r}21 \\
17 \\
4 \\
4 \\
14 \\
4 \\
9 \\
0 \\
11\end{array}$ & $\begin{array}{l}1 \\
3 \\
1 \\
0 \\
1 \\
0 \\
0 \\
0 \\
0\end{array}$ & $\begin{array}{l}1 \\
1 \\
0 \\
0 \\
1 \\
0 \\
0 \\
4 \\
0\end{array}$ \\
\hline Totals & 176 & 1 & 7 & 84 & 6 & 7 \\
\hline
\end{tabular}

* Twenty of the 301 streptococci were not tested.

The isolation of penicillin-resistant organisms was not limited to patients who had received prophylactic penicillin (table V). In all, MICs of $0.25 \mu \mathrm{g}$ per $\mathrm{ml}$ or more were found for eight of 87 isolates $(9 \%)$ from patients who had received no prophylactic antibiotics, 15 of 97 isolates $(15 \%)$ from those 
TABLE VII

Susceptibilities to penicillin and clindamycin of streptococci other than $S$. faecalis isolated from sutures, in relation to the prophylactic regimen employed

\begin{tabular}{|c|c|c|c|c|}
\hline \multirow{3}{*}{$\begin{array}{l}\text { Prophylactic } \\
\text { antibiotic }\end{array}$} & \multicolumn{4}{|c|}{$\begin{array}{c}\text { Number of isolates of streptococci from } \\
\text { sutures with }\end{array}$} \\
\hline & \multicolumn{2}{|c|}{$\begin{array}{l}\text { a penicillin MIC } \\
(\mu \mathrm{g} \text { per ml }) \text { of }\end{array}$} & \multicolumn{2}{|c|}{$\begin{array}{l}\text { a clindamycin MIC } \\
(\mu \mathrm{g} \text { per } \mathrm{ml}) \text { of }\end{array}$} \\
\hline & $\leqslant 0.06$ & $>0 \cdot 12$ & $\leqslant 0.06$ & $>0 \cdot 12$ \\
\hline $\begin{array}{l}\text { None } \\
\text { Penicillin } \\
\text { Lincomycin and } \\
\text { clindamycin }\end{array}$ & $\begin{array}{r}19 \\
22 \\
9\end{array}$ & $\begin{array}{r}6 \\
19 \\
3\end{array}$ & $\begin{array}{r}24 \\
42 \\
7\end{array}$ & $\begin{array}{l}1 \\
0 \\
4\end{array}$ \\
\hline Statistical analysis* & \multicolumn{2}{|c|}{$\chi^{2}=3.96 ; \mathrm{p}<0.05$} & \multicolumn{2}{|c|}{$\chi^{2}=13.78 ; \mathrm{p}=0.0005$} \\
\hline
\end{tabular}

* For each set of sensitivity tests, results for organisms from patients receiving that antibiotic were compared with a combination of those from patients receiving the other antibiotic or no antibiotic in a $2 \times 2$ test; $\chi^{2}$ was corrected for small numbers by Yates' method.

who had received lincomycin and clindamycin, and 24 of $117(20 \%)$ isolates from those who had received penicillin. If the $S$. faecalis isolates from the latter two groups are excluded, those percentages are respectively $9 \%, 12 \%$ and $15 \%$.

Resistance to clindamycin (table VI) was in general less frequent than to penicillin, but all 11 strains of $S$. faecalis had an MIC in excess of $4 \mu \mathrm{g}$ per ml for clindamycin. Only 270 of the 290 other streptococci were tested for clindamycin sensitivity; six of these had an MIC of $0.25-4.0 \mu \mathrm{g}$ per $\mathrm{ml}$ and three of $>4.0 \mu \mathrm{g}$ per ml. All these resistant strains were isolated from patients who had received lincomycin and clindamycin prophylactically.

When the organisms isolated from sutures, other than $S$. faecalis, were compared, statistically significant differences emerged (table VII). Penicillin prophylaxis resulted in the emergence of penicillin-resistant but not of lincomycinresistant strains, and lincomycin-clindamycin prophylaxis resulted in the emergence of clindamycin-resistant but not penicillin-resistant strains.

\section{Sensitivities to other antibiotics}

The susceptibilities of all the streptococci, other than $S$. faecalis, to cephaloridine, tetracycline and erythromycin, are summarised in table VIII. Correlation is difficult because of the small numbers of organisms in some of the groups. However, excluding $S$. faecalis, there was some correlation between penicillin and cephaloridine sensitivity; and organisms showing some degree of resistance to cephaloridine (MIC $>0.12 \mu \mathrm{g}$ per $\mathrm{ml}$ ) were more commonly isolated from sutures after penicillin prophylaxis $(39 \%)$ than after no prophylaxis $(24 \%)$ or after clindamycin $(28 \%)$. We have no explanation for the 
TABLE VIII

Susceptibilities of all isolates other than $S$. faecalis to cephaloridine, tetracycline and erythromycin

\begin{tabular}{l|ccc}
\hline \multirow{2}{*}{ Antibiotic } & \multicolumn{3}{|c}{ Percentage of isolates that were } \\
& $\begin{array}{c}\text { fully } \\
\text { sensitive* }\end{array}$ & intermediate & resistant \\
\hline Cephaloridine & 79 & 15 & 6 \\
Tetracycline & 62 & 15 & 23 \\
Erythromycin & 95 & 3 & 2 \\
\hline
\end{tabular}

* MIC of cephaloridine and erythromycin $\leqslant 0.06 \mu \mathrm{g}$ per $\mathrm{ml}$, and of tetracycline $\leqslant 1.2 \mu \mathrm{g}$ per ml. $\dagger$ MIC of cephaloridine and erythromycin $0.12 \mu \mathrm{g}$ per ml to $1.0 \mu \mathrm{g}$ per ml, and of tetracycline $2 \cdot 5-10 \mu \mathrm{g}$ per $\mathrm{ml}$.

$\ddagger$ MIC of cephaloridine and erythromycin $>2.0 \mu \mathrm{g}$ per ml, and of tetracycline $>20 \mu \mathrm{g}$ per ml.

finding that a similar degree of resistance was found in only $12 \%$ of streptococci from teeth. Tetracycline resistance (MIC $>2.5 \mu \mathrm{g}$ per $\mathrm{ml}$ ) was common among streptococci from teeth $(42 \%)$ and had a similar frequency among streptococci from sutures. Resistance to erythromycin (MIC $>0 \cdot 12 \mu \mathrm{g} \mathrm{per} \mathrm{ml),}$ as to clindamycin, was uncommon among streptococci from teeth $(2 \%)$; a marked increase in the frequency of erythromycin resistance (to $16 \%$ ) was observed only among streptococci from the sutures of patients receiving clindamycin.

\section{Antibiotic content of the blood of patients}

Among patients treated with penicillin, assays were performed on 17 blood samples collected at the beginning of the operation and 18 collected at the end. Mean penicillin concentrations were $4.4 \mu \mathrm{g}$ per $\mathrm{ml}$ (standard deviation $\pm 2 \cdot 1$ ) and $3.5 \mu \mathrm{g}$ per $\mathrm{ml}$ (standard deviation \pm 1.9 ). Among those given lincomycin, assays were performed on 21 pre-operative and 20 post-operative samples, and mean lincomycin concentrations were $7.9 \mu \mathrm{g}$ per $\mathrm{ml}$ (standard deviation $\pm 2 \cdot 2$ ) and $7.0 \mu \mathrm{g}$ per $\mathrm{ml}$ (standard deviation $\pm 1 \cdot 7$ ).

\section{Discussion}

This study was undertaken to compare the effect of lincomycin and penicillin as separate prophylactic agents when administered during dental extraction. The case for an alternative to penicillin is based on the argument that patients having a dental extraction some weeks before an operation on the heart should be given an antibiotic that, apart from being effective in preventing endocarditis, will not result in the emergence of a bacterial population that is resistant to antibiotics that will be used prophylactically at the time of the cardiac operation. For this reason, the prophylactic regimens used could not be entirely randomised, and the group of patients receiving lincomycin had more severe dental disease and more extensive dental operations, both of which factors might well have resulted in more organisms gaining access to 
the bloodstream, making prophylaxis more difficult. There was, however, no obvious difference between the incidence of bacteriaemia in patients undergoing dental clearance and in those having only extraction of wisdom teeth.

The organisms isolated from teeth belonged largely to species that we had expected to find there, namely $S$. sanguis, $S$. mitior, $S$. mutans and $S$. milleri. There were relatively few isolates of $S$. salivarius, not unexpectedly as the tongue is the preferred habitat of this organism. S. faecalis was not isolated, and there was only one isolate of another enterococcus. This finding is in agreement with that of most investigators except, possibly, Ross (1972) who found $S$. faecalis in the saliva of $42 \%$ of 50 school-children.

Although the number of streptococci isolated from blood was small, it was interesting that $S$. mitior and unclassified "viridans" streptococci were relatively more common in the blood than on the teeth, and that among patients given no prophylaxis $S$. milleri was the commonest single species isolated; $S$. sanguis was somewhat more rare in the blood than on the teeth, but none of these differences is statistically significant. Porterfield (1950) found that most of the streptococci found in the blood after dental extraction were $S$. mitior, with a few $S$. sanguis.

The sutures removed from the patients' gums 5-7 days after dental treatment were shown, in a preliminary study, to have a streptococcal flora similar to that of the gums themselves, and were, therefore, a convenient means of sending a sample to the laboratory. Culture of the sutures provided the answer to one of our major questions, in that $S$. faecalis was isolated only from them and not from the teeth, whose flora was assumed to be unaffected by chemotherapy. Furthermore, S. faecalis was isolated only from patients who had had a course of an antibiotic. Chemotherapy with either penicillin or clindamycin therefore resulted in the appearance of $S$. faecalis in the oral flora. This finding is in some contrast to that of Sukchotiratama et al. (1975) who reported no $S$. faecalis in the oral flora after giving penicillin and clindamycin. However, they worked on samples from normal volunteers.

Streptococci of other types were isolated from sutures in much the same proportions as from teeth, and an assessment of the susceptibility of these organisms gave the remainder of the answer to our first major question. Resistant isolates of each of the streptococcal species were detected. Investigation of organisms from teeth and blood showed that similar organisms were present before chemotherapy, but were detectable less often, presumably because they were in relatively small numbers.

Our results on the distribution of the various species of streptococci and their antimicrobial susceptibilities support the hypothesis that the oral streptococcal flora becomes resistant to penicillin after penicillin treatment, both by the acquisition of $S$. faecalis not normally present in the mouth, and by the selection of resistant populations of the resident species. Similarly the administration of clindamycin led to the acquisition of $S$. faecalis and small numbers of clindamycin-resistant variants of other species, a finding again in contrast to that of Sukchotiratama et al. in their studies on normal volunteers. There was evidence of cross-resistance, in organisms other than $S$. faecalis, 
between penicillin and cephaloridine, and to some extent between clindamycin and erythromycin, findings largely in agreement with those of Sprunt, Redman and Leidy (1968), Paterson and Madden (1969) and Spencer et al. (1970). It follows that our practice of administering lincomycin and clindamycin to patients who would later require penicillin prophylaxis, to prevent the emergence of a penicillin-resistant flora by the time penicillin was administered, was probably well founded.

The second major area of study was the comparison of the effects of penicillin and lincomycin on dental bacteriaemia. The incidence of postextraction streptococcal bacteriaemia was high, in keeping with the findings of others (Okell and Elliott 1935; Jones et al., 1970; Cutcher et al., 1971). It was apparently abolished by penicillin but not completely by lincomycin in the dose that we used. However, it became clear during the course of the study that the interpretation of the results of blood cultures was difficult. Dental bacteriaemia lasts for about 10 minutes, and organisms that are going to survive presumably attach themselves to damaged heart valves during that time. No antibiotic can kill organisms with sufficient rapidity to remove them in this phase (Durack and Petersdorf, 1973). Their exposure to antibiotic presumably then changes, and we cannot mirror these changes in a standard blood-culture system. A major difference in vitro is that the blood is immediately diluted-in our system about five-fold. Concentrations of penicillin would thus drop to a mean of about $0.7 \mu \mathrm{g}$ per $\mathrm{ml}$ for penicillin and $1.4 \mu \mathrm{g}$ per $\mathrm{ml}$ for lincomycin. Because the modal MIC for lincomycin is about four to eight times that for penicillin for these organisms, lincomycin might be at an increased disadvantage as a result of this dilution. Having been diluted, the antibiotics then presumably decline in concentration in the blood-culture bottle, penicillin more quickly than lincomycin, but neither as quickly as they would in vivo, nor, in the case of penicillin, as quickly as after the addition of penicillinase. As a result of these factors, we can conclude only that organisms causing dental bacteriaemia did not survive penicillin but that some did survive lincomycin, in the blood-culture bottles. The relevance of either of these findings to in-vivo events is impossible to assess, and one must use experimental models to assist in their interpretation (Durack and Petersdorf, 1973). It is possible that bacteristatic agents may be useless despite their ability to suppress bacteria in blood-culture systems (Southwick and Durack, 1974).

\section{SUMMARY}

Patients undergoing dental extractions were non-randomly allocated to three groups, one of which received no antibiotic, one benzylpenicillin followed by oral penicillin for 5 days, and the third intramuscular lincomycin followed by oral clindamycin. Dental extraction was performed at the beginning of the course of chemotherapy. Streptococci were isolated from the extracted teeth, from blood cultures collected before and immediately after dental extraction, and from sutures removed from the gums 5-7 days after the operation. The species of these organisms was determined, and their susceptibilities to penicillin, clindamycin, cephaloridine, erythromycin and tetracycline were assessed. 
The majority of streptococci isolated from teeth belonged to the species Streptococcus sanguis, $S$. mitior, $S$. mutans and $S$. milleri. Occasional isolates of each of these organisms collected before the antibiotic could take effect were resistant to penicillin.

Three of these species, but not $S$. mutans, were the commonest streptococci to be isolated from the blood after dental extraction. Penicillin completely suppressed dental bacteriaemia under the conditions of our investigation, and lincomycin reduced the incidence by about 60 per cent.

The commonest streptococci from sutures were also $S$. sanguis, S. mitior, $S$. mutans and $S$. milleri; $S$. faecalis was also isolated, but only in patients who had received antibiotics. Among the non-faecalis organisms, penicillin resistance was significantly more frequent among isolates from patients given penicillin than from patients not given this antibiotic, and clindamycin resistance was significantly more frequent among isolates from patients given lincomycin and clindamycin than from patients not given these antibiotics.

\section{REFERENCES}

Bentley, D. W., Frank, T. and Hahn, J. J. 1971. Penicillin resistant oral streptococci. Antimicrob. Agents Chemother., 1970, p. 277.

Colman, G. AND Williams, R. E. O. 1972. Taxonomy of some human viridans streptococci. In Streptococci and streptococcal diseases: recognition understanding and management, edited by L. W. Wannamaker and J. M. Matsen, New York and London, p. 281.

Cutcher, J. L., GoldberG, J. R., Lilly, G. E. AND JoNes, J. C. 1971. Control of bacteremia associated with extraction of teeth. II. Oral Surg., 31, 602.

DruCKer, D. B. AND Jolly, M. 1971. Sensitivity of oral microorganisms to antibiotics. Br. dent. J., 131, 442.

Durack, D. T. AND Petersdorf, R. G. 1973. Chemotherapy of experimental streptococcal endocarditis. I. Comparison of commonly recommended prophylactic regimens. J. clin. Invest., 52, 592.

Garrod, L. P. and Waterworth, P. M. 1962. The risks of dental extraction during penicillin treatment. Br. Heart J., 24, 39.

Jones, J. C., Cutcher, J. L., Goldberg, J. R. And Lilly, G. E. 1970. Control of bacteraemia associated with extraction of teeth. Oral Surg., 30, 454.

Krumwiede, E. 1949. Penicillin resistance of non-haemolytic streptococci from rheumatic children receiving prophylactic penicillin. Pediatrics, 4, 634.

Naiman, R. A. ANd Barrow, J. G. 1963. Penicillin resistant bacteria in the mouths and throats of children receiving continuous prophylaxis against rheumatic fever. Ann. intern. Med., 58, 768.

OKell, C. C. AND ElliotT, S. D. 1935. Bacteraemia and oral sepsis, with special reference to the aetiology of subacute bacterial endocarditis. Lancet, 2,869 .

Parker, M. T. and Ball, L. C. 1976. Streptococci and aerococci associated with systemic infection in man. J. med. Microbiol., 9, 277.

Paterson, P. Y. AND MADDEn, G. M. 1969. Occurrence and erythromycin susceptibility of penicillin-resistant viridans streptococci in rheumatic fever patients on oral penicillin prophylaxis. Antimicrob. Agents Chemother., 1968, p. 323.

Phillips, I. AND WARREN, C. 1972. Antibiotic sensitivity of oral streptococci following penicillin, and of streptococci causing endocarditis. In Advances in antimicrobial and antineoplastic chemotherapy (Proc. 7th Int. Congr. Chemother., Prague, 1971), edited by M. Hejzlar, Baltimore, p. 745 .

PorTERFIELD, J. S. 1950. Classification of the streptococci of subacute bacterial endocarditis. J. gen. Microbiol., 4, 92. 
Ross, P. W. 1972. The occurrence of potentially pathogenic bacteria in the mouth. In Host resistance to commensal bacteria, edited by T. MacPhee, Edinburgh and London, p. 34.

RusSELL, A. L. 1956. A system of classification and scoring for prevalence surveys of periodontal disease. J. dent. Res., 35, 350.

Southwick, F. S. AND Durack, D. T. 1974. Chemotherapy of experimental streptococcal endocarditis. III. Failure of a bacteriostatic agent (tetracycline) in prophylaxis. J. clin. Path., 27, 261.

SPenCer, W. H., Thornsberry, C., Moody, M. D. AND Wenger, N. K. 1970. Rheumatic fever chemoprophylaxis and penicillin resistant gingival organisms. Ann. intern. Med., $73,683$.

SPRUNT, K., Redman, W. AND Leidy, G. 1968. Penicillin resistant alpha streptococci in pharynx of patients given oral penicillin. Pediatrics, 42, 957.

StiRland, R. M. AND ShOtTs, N. 1967. Antibiotic-resistant streptococci in the mouths of children treated with penicillin. Lancet, 1, 405.

Sukchotiratama, M., Linton, A. H. AND Fletcher, J. P. 1975. Antibiotics and the oral streptococci of man. J. appl. Bact., 38, 277.

Tozer, R. A., Boutflower, S. AND Gillespie, W. A. 1966. Antibiotics for prevention of bacterial endocarditis during dental treatment. Lancet, 1, 686. 